Article

\title{
Sustaining Medicinal Barks: Survival and Bark Regeneration of Amphipterygium adstringens (Anacardiaceae), a Tropical Tree under Experimental Debarking
}

\author{
Leonardo Beltrán-Rodríguez ${ }^{1, *} * \mathbb{D}$, Juan Ignacio Valdez-Hernández ${ }^{2}$, Alfredo Saynes-Vásquez ${ }^{3} \mathbb{D}$, José Blancas ${ }^{4, *} *$, \\ José Antonio Sierra-Huelsz ${ }^{5}{ }^{(}$, , Sol Cristians ${ }^{1}{ }^{(0)}$, Andrea Martínez-Ballesté ${ }^{1}$, Angélica Romero-Manzanares ${ }^{2}{ }^{(0)}$, \\ Mario Luna-Cavazos ${ }^{2}$, Ma. Amparo Borja de la Rosa ${ }^{6}$, Elizandro Pineda-Herrera ${ }^{2}$, Belinda Maldonado-Almanza ${ }^{4}$, \\ Gregorio Ángeles-Pérez ${ }^{2}$, , Tamara Ticktin ${ }^{7} \mathbb{D}$ and Robert Bye ${ }^{1}$
}

check for

updates

Citation: Beltrán-Rodríguez, L.; Valdez-Hernández, J.I.; SaynesVásquez, A.; Blancas, J.; SierraHuelsz, J.A.; Cristians, S.; MartínezBallesté, A.; Romero-Manzanares, A.; Luna-Cavazos, M.; Borja de la Rosa, M.A.; et al. Sustaining Medicinal Barks: Survival and Bark

Regeneration of Amphipterygium adstringens (Anacardiaceae), a

Tropical Tree under Experimental Debarking. Sustainability 2021, 13, 2860. https://doi.org/10.3390/ su13052860

Academic Editor:

Richard Niesenbaum

Received: 11 February 2021

Accepted: 2 March 2021

Published: 6 March 2021

Publisher's Note: MDPI stays neutral with regard to jurisdictional claims in published maps and institutional affiliations.

Copyright: (c) 2021 by the authors. Licensee MDPI, Basel, Switzerland. This article is an open access article distributed under the terms and conditions of the Creative Commons Attribution (CC BY) license (https:// creativecommons.org/licenses/by/ $4.0 /)$.
1 Jardín Botánico, Instituto de Biología, Universidad Nacional Autónoma de México, Ciudad de México 04510, Mexico; sol.cristians@ib.unam.mx (S.C.); andrea.martinez@ib.unam.mx (A.M.-B.); bye.robert@gmail.com (R.B.)

2 Colegio de Postgraduados Campus Montecillo, Texcoco 56230, Mexico; ignaciov@colpos.mx (J.I.V.-H.); dahly@colpos.mx (A.R.-M.); mluna@colpos.mx (M.L.-C.); elherrera2001@yahoo.com.mx (E.P.-H.); gangeles@colpos.mx (G.Á.-P.)

3 Instituto Saynes de Investigaciones sobre Cultura, Lengua y Naturaleza, Juchitán 70000, Mexico; pichossaynes@gmail.com

4 Centro de Investigación en Biodiversidad y Conservación (CIByC), Universidad Autónoma del Estado de Morelos, Cuernavaca 62209, Mexico; bely@uaem.mx

5 People and Plants International, Bristol, VT 05443, USA; jashpat@gmail.com

6 División de Ciencias Forestales, Universidad Autónoma Chapingo, Texcoco 56230, Mexico; aborja@correo.chapingo.mx

7 Botany Department, University of Hawaii at Manoa, 3190 Maile Way, Honolulu, HI 96822, USA; ticktin@hawaii.edu

* Correspondence: leonbeltranrodriguez@gmail.com (L.B.-R.); jose.blancas@uaem.mx (J.B.); Tel.: +52-777-3297000 (ext. 3306) (J.B.)

Abstract: Commercial harvests can threaten tree species harvested for their bark. Amphipterygium adstringens is a dioecious tree, endemic to the tropical dry forests of Mexico, where it is intensively harvested for its medicinal bark. Limited information hinders developing sustainable management strategies for A. adstringens. We assessed bark regeneration for male and female trees, and evaluated the effect of tree sex and diameter, debarking treatments and cutting seasons on bark regeneration and tree survival rates. Bark regeneration was higher for wet season harvested trees (vs. dry), regardless of their sex. Bark regeneration was higher on female than on male trees. There were significant interactions of harvest season, harvest treatment and tree sex diameter on bark regeneration and survival. Overall, the highest bark regeneration rates occurred in female trees with $\geq 20.1 \mathrm{~cm}$ diameter that were wet season harvested with a 50\% debarking intensity. Consequently, wet season and intermediate intensity harvests appear to foster sound management, but we recommend against targeting exclusively a single demographic group (i.e., large female trees) due to potential negative impacts on species demography and bark supply. A grounded strategy for sustaining bark harvest would also need to take into account relevant aspects of local socio-ecological context, including harvest interactions with other land uses.

Keywords: Mexico; tropical dry forest; non-timber forest products; forest management; medicinal plant

\section{Introduction}

Non-timber forest products (NTFPs) are an important component of rural livelihoods [1], and medicinal plants are among the most salient and culturally significant of these resources $[2,3]$. Within the large diversity of locally used medicinal species, some of 
them are increasingly known and used outside their natural areas of distribution, leading to their commercial harvest [2].

Booming demand is often associated with unsustainable harvest of NTFPs, representing a major threat for many species [1,2]. Facing intensified harvests, some NTFP species are more vulnerable than others. Species life history and the part of the plant that is harvested are major factors that determine NTFP harvest tolerance. Bark harvest can have a high negative impact as it alters the structure and physiological continuity of adult woody plants, thus threatening their survival [2-4]. Because medicinal barks are some of the most traded NTFPs, there is a need to determine their maximum sustainable harvest rates as key elements for their long-term management and conservation for these species [5-7].

A total of 802 NTFP species are traded in Mexico [8], 212 of those species have medicinal barks that are commercialized in local, regional, and national markets, and are even exported to the USA and Europe [9]. Because of this demand, evidence of unsustainable harvest is widespread, including declining populations and local extinctions [10,11]. In the Balsas River basin in southern Mexico, medicinal bark species have the highest conservation risk among all medicinal plant species harvested in the region [12].

Post-harvest bark regeneration varies across species and is affected by a range of factors, including $[5,6,13,14]$ : the amount of bark harvested, incision depth, harvest season, plant physiology, microclimate and exudate presence [15-17]. However, how bark regeneration is affected by these factors varies between species and ecosystems, thus broad re-cmmendations for sustaining bark harvests are not possible. For example, for 12 tree species of a tropical forest of Benin, West Africa, low debarking intensity (without damage in the vascular cambium) increased bark regeneration rates and survival, reducing the mortality caused by predatory insects [5]. In a follow-up study, the mortality of those 12 tree species increased with $100 \%$ debarking in the wet season, whereas bark regeneration rate was associated with larger tree diameter and bark harvest intensities during wet season [6]. In contrast, in the Caatinga forests of Brazil, bark regeneration rates of Myracrodruon urundeuva Allemão [13] and Stryphnodendron rotundifolium Mart. [13,14] were not affected by precipitation but were heavily associated with harvest intensity. That is, higher regeneration rates were observed when larger bark areas were removed. In India, bark regeneration of Terminalia arjuna (Roxb. ex DC.) Wight \& Arn. and Litsea glutinosa (Lour.) C.B. Rob. varies as a function of tree size (diameter), debarking technique and season [18].

Despite the importance and diversity of Mexican species harvested for their medicinal bark, harvest impacts have been studied for only two species: Hintonia latiflora (DC.) Bullock and Amphipterygium adstringens (Schltdl.) Standl. $[8,12,19,20]$. In particular, A. adstringens is among the most intensively harvested medicinal species in Mexico due its high commercial demand [9]; 57.5 tons of bark per year are estimated to be harvested over a small region in south-central Mexico [21].

The only study [19] that evaluated the effect of bark harvesting in A. adstringens found that this species has high bark regeneration capacity, regardless of tree diameter, especially if debarking impacts the vascular cambium and is made during the wet season. While that study provided useful information, it had several significant limitations. First, A. adstringens is a dioecious tree; the potential differences in bark regeneration between sexes was not considered, an important limitation considering that female trees could potentially have a lower regeneration rate than males due the higher cost of reproduction $[13,22]$. Second, that study only assessed the effect of a single harvest intensity, which did not allow the determination of the maximum sustainable individual bark harvest $[19,23]$. Third, that study's small sample size $(n=20)$, unbalanced data across categories and incomplete information, call into question the validity of drawing inferences from it $[19,23]$. Building upon previous studies, we aimed to assesses the survival and bark regeneration of $A$. adstringens under experimental debarking. More specifically, our research objectives were: (i) to qualitatively characterize and compare tree response to bark harvest between sexes; (ii) to assess the effect of and potential interactions between tree sex, diameter, harvest intensity and cutting 
season on bark thickness regeneration and tree survival, and (iii) to analyze our results within the local socio-ecological context and existing research to generate sustainable management strategies for this NTFP species. We expected that $A$. adstringens would show differences in bark regeneration and survival between sexes. In particular we expected that male trees would have higher rates of bark regeneration than female trees, particularly for large diameter trees that were harvested in the wet season. All in all, to our knowledge this is the first study that evaluates the effect of the interactions between these factors, particularly the influence of tree sex on bark regeneration and survival.

\section{Materials and Methods}

\subsection{Study Area}

The research was conducted in a tropical dry forest (TDF) in the lands of El Limón de Cuauchichinola community, located in the Sierra de Huautla Biosphere Reserve (SHBR) $\left(18^{\circ} 33^{\prime} 17.3^{\prime \prime}-18^{\circ} 29^{\prime} 5.4^{\prime \prime} \mathrm{N}\right.$ and $\left.98^{\circ} 57^{\prime} 43.2^{\prime \prime}-98^{\circ} 54^{\prime} 10.1^{\prime \prime} \mathrm{W}\right)$, in the SE of Morelos state, south-central Mexico. The SHBR area ranges from 650 to $1790 \mathrm{~m}$ amsl, the climate is hot sub-humid with summer rain regime (sensu Köeppen modified by García) and a sixmonth-long dry season [24]. The mean annual temperature is $22.7^{\circ} \mathrm{C}$ and the average annual precipitation is $863 \mathrm{~mm}$, with $90 \%$ of the rain concentrated between May and October [25]. Tropical dry forest is the dominant ecosystem in the region, which covers more than $90 \%$ of the total area, more than half of it is covered by secondary forest patches in different successional stages [26]. The vascular flora is estimated at 456 species, 266 genera and 76 families. Amphipterygium adstringens is one of the structurally dominant species, particularly in secondary tropical dry forests, coexisting with other taxa such as Pachycereus grandis Rose, Lysiloma divaricatum (Jacq.) J.F. Macbr., Randia echinocarpa DC., Conzattia multiflora (B.L. Rob.) Standl. and Bursera spp. [26]. In 2007, the population in the SHBR was 23,544 inhabitants, living in 31 communities, who were mostly dedicated to small-scale agriculture (maize, beans, and sorghum) and extensive cattle ranching [27]. Remittances, government subsidies and harvest of forest products are also relevant components of local livelihoods $[28,29]$.

\subsection{Study Species}

Amphipterygium adstringens, commonly known as Cuachalalate, is a dioecious tree, endemic to Mexican tropical dry forests [30] where it can be a dominant species with densities reaching 136 ind. $\mathrm{ha}^{-1}$ [26]. The trees reach up to $15 \mathrm{~m}$ in height, with a diameter at breast height (DBH, measured at $1.30 \mathrm{~m}$ from the ground) of up to $35 \mathrm{~cm}$ (usually between 20 and $25 \mathrm{~cm}$ ) and a dense, umbrella-shaped canopy [26,30]. The bark of $A$. adstringens is highly valued in traditional medicine and used in the treatment of over 23 different diseases [31]. Its biomedical properties have been extensively studied, including astringent and hypocholesterolemic properties, as well as its effectiveness for treating cancer and gastritis [32-34].

The phytochemical constituents of Cuachalalate bark are categorized in two main groups: triterpenes and long-chain phenolic compounds [23,32,34]. The former group is of greater interest due to masticadienonic and $3 \alpha$-hydroxymasticadienonic acids that are the main constituents of the bark's organic extract [32]. The latter compound has been designated as the reference standard for quality control analysis of the crude drug [35].

Cuachalalate bark is traded at different geographic scales, mostly in regional and national markets, but also reaching the international markets [21]. The outer bark (periderm) of Cuachalalate is between 1-2 cm thickness, grayish brown color, with rhytidome generation just in protuberances $[23,36]$. Inner bark (secondary functional phloem and vascular cambium) is $0.4-0.8 \mathrm{~cm}$ thick $[23,36]$ and is creamy pink to white color in male trees but reddish in female trees. Traditional preference for employing the reddish bark is related to higher concentrations of such active compounds as masticadienonic and $3 \alpha$-hydroxymasticadienonic acids, among others $[23,32,34]$. 


\subsection{Current Harvest Practices}

Cuachalalate bark is harvested at different intensities depending on the size of the demand, ranging from household remedy $[10,12,23]$ to extensive commercial extraction $[37,38]$. When debarking is conducted for personal or family use, only relatively small bark pieces are taken. Such harvests usually occur whenever needed, regardless of the time of the year [9]. In contrast, in localities where Cuachalalate is commercially harvested [33], debarking the complete bole is a common practice, leading to a high tree mortality (up to $60 \%)[9,39]$. Other destructive practices include the debarking of smaller branches [32] and felling of whole trees for facilitating the debarking process $[37,38]$. Commercial bark extraction is commonly carried out in the dry season (usually from February to early June), when the recently harvested bark is left on site to dry for a few days and then transported [39]. The harvest of ca. $50 \%$ of the tree bark in long strips is practiced by some harvesters. Commercial bark extraction tends to disproportionately target female trees (although not uniquely), as they have redder barks, a trait that harvesters and buyers associate with stronger medicinal potency [23,34]. An official debarking manual also recommends 50\% intensity debarking but suggests the use of more complex practices that include debarking multiple small bark plates (leaving mosaic pattern on the stem) and covering the wounds in plastic to maintain their moisture [39]. This official manual proposes wet season debarking to ensure faster regeneration [39]. To our knowledge, the various communities with forest management plans that include the commercial harvest of Cuachalalate bark are not actually extracting it. Conversely, those communities known to be intensively extracting this medicinal bark do not have an official management plan.

\subsection{Experimental Debarking and Bark Regeneration Assessment}

Experimental debarking of $A$. adstringens was performed on 72 individual trees (36 per sex) distributed in 6 ha of tropical dry forest, belonging to two diametric categories: $\mathrm{DBH} \geq 10 \mathrm{~cm} \leq 20 \mathrm{~cm}$, and $\mathrm{DBH} \geq 20.1 \mathrm{~cm}$ (up to $35 \mathrm{~cm}$, which was the maximum DBH recorded), with half of the trees debarked during the dry season and half debarked during the wet season. Debarking consisted of the mechanical removal of rectangular bark pieces in a basipetal direction using a machete, from the upper stem to the tree base, cutting the outer and inner bark (periderm and secondary functional phloem, respectively) to the secondary functional xylem (wood). Preliminary evidence suggests that $A$. adstringens bark regeneration is positively related with mechanical intensity [19]; thus, our research intended to test the effects of a wider range of mechanic damage intensities on this species $[6,14]$.

In order to include part of the range of traditional debarking intensities registered in the study area of $A$. adstringens $[19,23,37,38]$, three treatments were established that varied in terms of the percentage of bark removed from the bole stem of each tree and applied to each diameter category and cutting season (wet and dry). These were: DI1 $=25 \%$, DI $=50 \%$ and DI $3=75 \%$ harvested bark. In total, there were three trees (replicates) per harvest intensity (DI) of each category of tree diameter and sex and seasons. For each tree, the bole was vertically divided in four equal parts $(25 \%, 50 \%, 75 \%$ and $100 \%)$, the bark was evenly removed on both sides (east and west) of the stem in every treatment, but the north and south sections were left untouched to allow regeneration (Figure 1a-c). We did not apply a $100 \%$ debarking treatment as it was reported to cause high mortality in A. adstringens (up to 60\% of debarked trees) [39]. Instead, we left some remnant bark needed to maintain the tree's functional connectivity, and some outer and inner bark tissues around which bark regeneration could be stimulated $[6,40]$.

Dry season experimental debarking of 36 trees (18 from each sex and nine of each sex per diameter category) was carried out in March 2015. The same sampling design was used for the wet season experimental debarking conducted in June 2016. Monitoring was conducted $24 \mathrm{~h}$ after bark removal, and then every two months over a two-year period. Survival was reported for each individual. A tree was considered dead when these signs were present: leaves absent during wet season, visible branch decay, signs of stem 
contraction, sap did not flow after a small incision was practiced. In each case inferred causes of tree death and the thickness $(\mathrm{cm})$ of regenerated bark were measured.

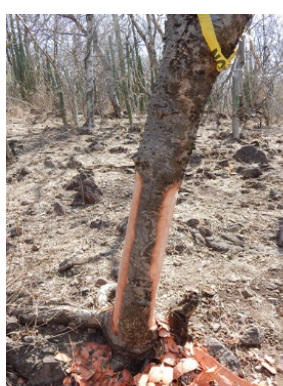

(a)

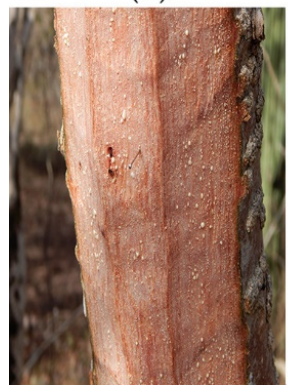

(d)

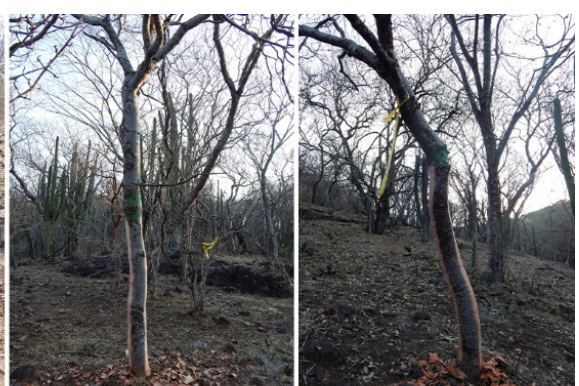

(b)

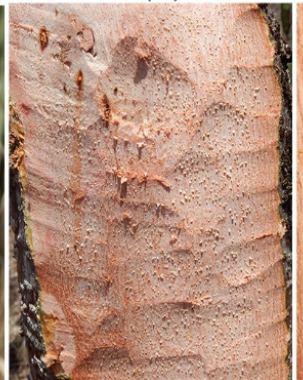

(e) (c)

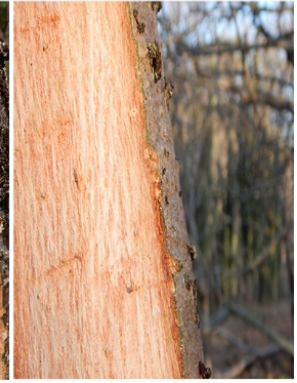

(f)

Figure 1. Debarking treatments and tree response in Amphipterygium adstringens. Subfigures show the debarking intensity treatments: (a) $2 \times 25 \%$; (b) $2 \times 50 \%$; (c) $2 \times 75 \%$. Subfigure (d) use of metal pins to monitoring bark thickness, and the presence of latex few minutes after debarking. Subfigures (e) latex $24 \mathrm{~h}$ after debarking; (f) outer bark covering (bright green tissue) in the edge of the wound.

Bark regeneration was defined here as the growth of new living tissue over the previously damaged surface. We measured bark regeneration using entomological stainless pins fixed on the recovering tissue. Every two months we measured the difference between the initial length of the pin standing out of the tissue (immediately after the wound) and the remaining pin length standing out of the growing tissue using a digital caliper (Figure 1d). Twelve pins were fixed in each tree, forming a zig-zag pattern along the wound (six per wound in each side of the tree), with a homogeneous separation depending on the length of tree bole. The bark thickness regeneration rate was calculated every two months through the average (12 measurements per individual) of living tissue $(\mathrm{cm})$ covering the pins.

According to Solares [23], A. adstringens also presents lateral bark regeneration. However, in our study, only one of the 72 debarked individuals developed new tissue from the edges of the wound toward its center, thus we did not carry out further analysis of this.

\subsection{Data Analysis}

We applied a Wilcoxon Test for independent samples to test for significant differences $(p \leq 0.05)$ in bark regeneration as a function of debarking season and tree sex. The debarked individuals followed a combination of four factors and nine treatments: (i) bark removal intensities (25\%, 50\% and 75\%); (ii) diametric categories (DBH I and DBH II); (iii) cutting seasons (wet and dry); and (iv) sex (female vs. male). To evaluate if there was an effect of these factors on bark thickness $(\mathrm{cm})$ and bark regeneration capacity, a Univariate Factorial Variance Analysis was applied, which included interactions between factors and treatments [41]. Subsequently, post hoc tests were performed only for those interactions that were statistically significant $(p \leq 0.05)$, and we adjusted for multiple comparisons using the Bonferroni correction [42] and the test of coefficients contrasts of the treatments of each factor [41]. The analyzes were carried out in SPSS v. 21 [43].

To test if the bark removal intensity, cutting season, sex and diametric category significantly affected the survival of the harvested individuals, we used a generalized 
linear model (hereafter GLM) with binomial distribution and logit function [44]. To adjust the model and to avoid that the estimation of the logistic curve was uncertain due to the "complete separation" of the data, Firth's bias reduction method was applied [45], by means of the use of the "logistf" package in the R software [46].

\section{Results}

\subsection{Qualitative Description of Bark Regeneration}

Qualitatively, A. adstringens had a similar process of bark regeneration in both sexes, regardless of diameter categories and debarking intensities, but some differences were observed between dry and wet season. A few minutes after the experimental bark removal, the wound was covered with an abundant whitish latex that would help to avoid desiccation and the attack of fungi or pathogens (Figure 1d). Twenty-four hours later the whole wound surface remained covered with dry latex, with some additional secretion of latex, which formed a protective layer of sticky appearance (Figure 1e). On the wound edges, the secretion of adhesive resins was observed, giving the phelodermis (a green tissue of the outer bark) a bright appearance (Figure 1f). This resin was observed to be more abundant during the wet season.

Lateral regeneration was only observed in one female individual 65 days after dry season debarking. In this case abundant reddish-brown parenchymal tissue grew from the wound edge inwards, and signs of desiccation and rot in the central area, with a blackish aspect, was observed (Figure 2a). For the rest of the trees wound colors showed variation associated with the moisture gradient in which they were found, where individuals with reddish-black wounds included those in a moister location (downhill) and those debarked during the wet season (Figure 2b); in contrast, individuals with reddish-brown wounds tended to be those in a lower humidity location (uphill) and those debarked during the dry season (Figure 2c). In all cases abundant sticky and sweet-scented resin covered the wound. Resin quantity was observed to be greater during the wet season (Figure 2d).

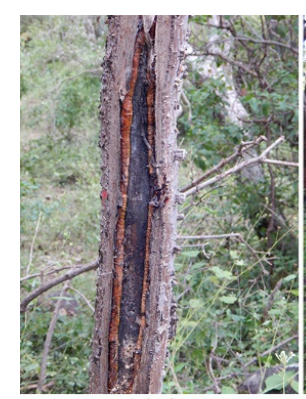

(a)

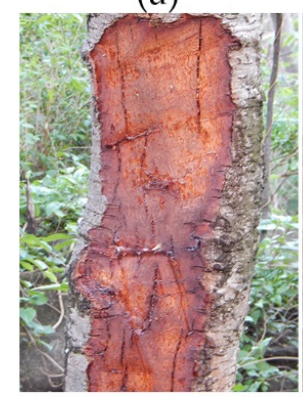

(d)

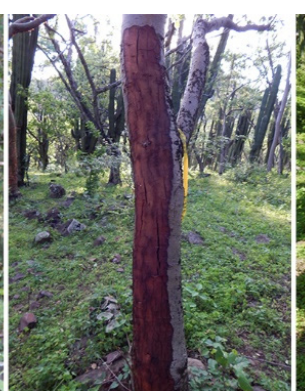

(b)

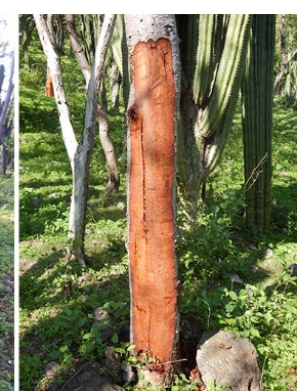

(c)

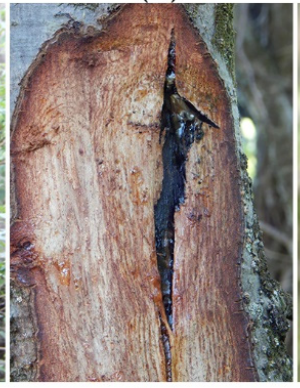

(e)

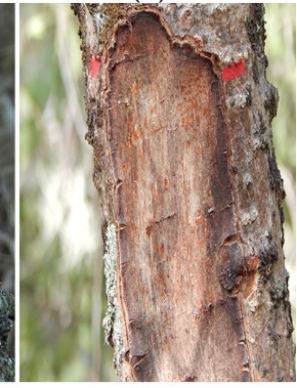

(f)

Figure 2. Bark regeneration in Amphipterygium adstringens: (a) lateral regeneration; (b) smooth and dry wound (without resin), with black-reddish aspect and indeterminate cracking pattern; (c) smooth and dry wound, reddish-brown and vertical fissures; (d) wound covered with sticky reddish resin; (e) wound covered mainly with reddish resin and in some areas of the wood presenting blackishbrown resin that covers the interior of the wound; (f) separation of the regenerated outer bark with respect to the non-debarked. 
Over the regenerating surface, all trees showed cracking patterns in different directions (vertical, horizontal and indeterminate) (Figure 2b), with dominance of vertical direction (Figure 2c), arguably due to the loss of moisture in the wood (contraction) when the wound was exposed and its eventual rehydration (expansion) once the wet season had been established. The orientation of the wound (east or west) was not associated with the color of the wound or the fissure pattern. Another characteristic observed was the presence of dark brown resin inside the cracks, an indication of the internal capacity in this species to coat the wounds (Figure 2e). The detachment of the outer bark at the edges of the wound was also observed, a process generated by the regeneration activity below the damaged surface (Figure 2f).

\subsection{Quantitative Evaluation of Bark Regeneration}

Regardless of the qualitative similarities in bark regeneration between sexes, quantitively, highly significant differences were found in the regeneration capacity of this structure between cutting seasons (wet vs. dry). Both male $(\mathrm{W}=24,280, p<0.0001$ ) and female $(\mathrm{W}=25,026, p<0.0001)$ trees displayed higher regeneration during the wet season. Overall, differences between the sexes were found $(W=250,306, p<0.001)$, with female trees having a significantly higher average regeneration rate compared to males: $0.54 \pm 0.39 \mathrm{~cm}_{\text {year }}^{-1}\left(0.13 \pm 0.17 \mathrm{~cm}_{\text {year }}{ }^{-1}\right.$ in dry and $0.77 \pm 0.31 \mathrm{~cm}$ year $^{-1}$ in wet seasons) vs. $0.46 \pm 0.35 \mathrm{~cm}_{\text {year }}{ }^{-1}\left(0.09 \pm 0.10 \mathrm{~cm}\right.$ year ${ }^{-1}$ occurred in the dry and $0.69 \pm 0.28 \mathrm{~cm}$ year $^{-1}$ in wet seasons), respectively (Table 1). All the individuals that survived to debarking closed the wounds, but the thickness regeneration showed variation with respect to the depth of the cut made to each tree according to its size. On average, male trees regenerated $40 \%$ of the bark area removed within two years when it was done during the dry season, whereas the female trees regenerated $45 \%$. For the wet season, the rate of regeneration increased to $89 \%$ in male trees and $93 \%$ in females.

Table 1. Descriptive statistic of bark regeneration (thickness increment) in Amphipterygium adstringens male and female trees, and as a function of cutting seasons: wet vs. dry; the diameter categories: DBH $1 \leq 20 \mathrm{~cm}$ and DBH 2 $\geq 20.1-35$; and debarking intensity treatments: T1 $=2 \times 25 \%, \mathrm{~T} 2=2 \times 50 \%$ and $\mathrm{T} 3=2 \times 75 \%$. The mean represents the average value of the bark growth of three individuals over two measured years.

\begin{tabular}{|c|c|c|c|c|c|c|c|c|}
\hline Sex & Debarking Season & Diameter Category & Treatment & Mean $(\mathrm{cm})$ & Standard Error & Variation Coefficient & Median & Variance \\
\hline \multirow{12}{*}{ Male } & \multirow[t]{6}{*}{ Dry } & DBH1 & $\mathrm{T} 1$ & 0.15 & 0.01 & $60.02 \%$ & 0.15 & 0.008 \\
\hline & & DBH1 & $\mathrm{T} 2$ & 0.14 & 0.02 & $95.23 \%$ & 0.09 & 0.01 \\
\hline & & DBH1 & T3 & 0.13 & 0.01 & $70.80 \%$ & 0.1 & 0.008 \\
\hline & & DBH2 & $\mathrm{T} 1$ & 0.13 & 0.01 & $61.12 \%$ & 0.12 & 0.006 \\
\hline & & DBH2 & $\mathrm{T} 2$ & 0.13 & 0.01 & $62.14 \%$ & 0.13 & 0.007 \\
\hline & & DBH2 & $\mathrm{T} 3$ & 0.1 & 0.01 & $91.50 \%$ & 0.1 & 0.008 \\
\hline & \multirow[t]{6}{*}{ Wet } & DBH1 & $\mathrm{T} 1$ & 0.7 & 0.03 & $36.05 \%$ & 0.74 & 0.063 \\
\hline & & DBH1 & $\mathrm{T} 2$ & 0.76 & 0.03 & $27.47 \%$ & 0.81 & 0.043 \\
\hline & & DBH1 & T3 & 0.74 & 0.03 & $27.75 \%$ & 0.78 & 0.043 \\
\hline & & DBH2 & $\mathrm{T} 1$ & 0.41 & 0.05 & $99.20 \%$ & 0.39 & 0.171 \\
\hline & & DBH2 & $\mathrm{T} 2$ & 0.76 & 0.03 & $27.39 \%$ & 0.79 & 0.043 \\
\hline & & DBH2 & $\mathrm{T} 3$ & 0.78 & 0.03 & $27.69 \%$ & 0.8 & 0.04 \\
\hline \multirow{12}{*}{ Female } & \multirow[t]{6}{*}{ Dry } & DBH1 & $\mathrm{T} 1$ & 0.23 & 0.03 & $91.08 \%$ & 0.17 & 0.04 \\
\hline & & DBH1 & $\mathrm{T} 2$ & 0.05 & 0.01 & $164.23 \%$ & 0.01 & 0.007 \\
\hline & & DBH1 & T3 & 0.15 & 0.02 & $97.21 \%$ & 0.14 & 0.023 \\
\hline & & DBH2 & $\mathrm{T} 1$ & 0.3 & 0.03 & $61.53 \%$ & 0.34 & 0.035 \\
\hline & & DBH2 & $\mathrm{T} 2$ & 0.16 & 0.02 & $82.18 \%$ & 0.17 & 0.019 \\
\hline & & DBH2 & $\mathrm{T} 3$ & 0.26 & 0.03 & $66.53 \%$ & 0.22 & 0.03 \\
\hline & \multirow[t]{6}{*}{ Wet } & DBH1 & $\mathrm{T} 1$ & 0.65 & 0.06 & $70.11 \%$ & 0.87 & 0.208 \\
\hline & & DBH1 & $\mathrm{T} 2$ & 0.86 & 0.03 & $24.40 \%$ & 0.89 & 0.044 \\
\hline & & DBH1 & $\mathrm{T} 3$ & 0.71 & 0.05 & $56.15 \%$ & 0.87 & 0.161 \\
\hline & & DBH2 & $\mathrm{T} 1$ & 0.78 & 0.02 & $26.48 \%$ & 0.82 & 0.043 \\
\hline & & DBH2 & $\mathrm{T} 2$ & 0.79 & 0.02 & $25.63 \%$ & 0.82 & 0.041 \\
\hline & & DBH2 & $\mathrm{T} 3$ & 0.87 & 0.03 & $27.34 \%$ & 0.95 & 0.05 \\
\hline
\end{tabular}


The analysis of the univariate factor variance showed that only the two-way interactions season:treatment $(p \leq 0.031)$ and sex:diameter $(p \leq 0.006)$ had a significant influence on the bark regeneration of $A$. adstringens, although the Eta Partial Square value was relatively low (Table 2).

Table 2. Analysis of Univariate Factorial Variance test for Amphipterygium adstringens bark thickness regeneration (cm).

\begin{tabular}{|c|c|c|c|c|c|c|}
\hline Origin & Type III Sums of Squares & f.d. & Squared Mean & $\mathbf{F}$ & $p$ Value & Partial Eta Squared \\
\hline Corrected model & $10.195^{\mathrm{a}}$ & 23 & 0.443 & 7.183 & 0 & 0.775 \\
\hline Intercept & 27.355 & 1 & 27.355 & 443.241 & 0 & 0.902 \\
\hline Season & 8.08 & 1 & 8.08 & 130.924 & 0 & 0.732 \\
\hline Sex & 0.084 & 1 & 0.084 & 1.362 & 0.249 & 0.028 \\
\hline Diameter & 0.039 & 1 & 0.039 & 0.635 & 0.429 & 0.013 \\
\hline Treatment & 0.062 & 2 & 0.031 & 0.504 & 0.607 & 0.021 \\
\hline Season:Sex & 0 & 1 & 0 & 0.006 & 0.94 & 0 \\
\hline Season:Diameter & 0.009 & 1 & 0.009 & 0.151 & 0.699 & 0.003 \\
\hline Season:Treatment & 0.463 & 2 & 0.232 & 3.751 & 0.031 & 0.135 \\
\hline Sex:Diameter & 0.507 & 1 & 0.507 & 8.21 & 0.006 & 0.146 \\
\hline Sex:Treatment & 0.141 & 2 & 0.07 & 1.14 & 0.328 & 0.045 \\
\hline Diameter:Treatment & 0.118 & 2 & 0.059 & 0.956 & 0.392 & 0.038 \\
\hline Season:Sex:Diameter & 0.064 & 1 & 0.064 & 1.031 & 0.315 & 0.021 \\
\hline Season:Sex:Treatment & 0.089 & 2 & 0.045 & 0.724 & 0.49 & 0.029 \\
\hline Season:Diameter:Treatment & 0.142 & 2 & 0.071 & 1.149 & 0.325 & 0.046 \\
\hline Sex:Diameter:Treatment & 0.209 & 2 & 0.105 & 1.696 & 0.194 & 0.066 \\
\hline Season:Sex:Diameter:Treatment & 0.187 & 2 & 0.094 & 1.518 & 0.229 & 0.06 \\
\hline Error & 2962 & 48 & 0.062 & - & - & - \\
\hline Total & 40.513 & 72 & - & - & - & - \\
\hline Total corrected & 13.158 & 71 & - & - & - & - \\
\hline
\end{tabular}

${ }^{a} R^{2}=0.775 ;$ adjusted $R^{2}=0.667$.

In terms of the sex:diameter interaction, the adjustment for multiple comparisons using the Bonferroni correction indicated that bark regeneration of female trees with $\mathrm{DBH} \geq 20.1 \mathrm{~cm}$ was significantly higher $(p \leq 0.05)$ compared to small diameter $(<20.1 \mathrm{~cm})$ male trees (Figure 3a). Regardless of tree sex, the highest rates of bark regeneration occurred during wet season harvests, with the biggest differences being for the $50 \%$ bark harvest intensity (Figure 3b).

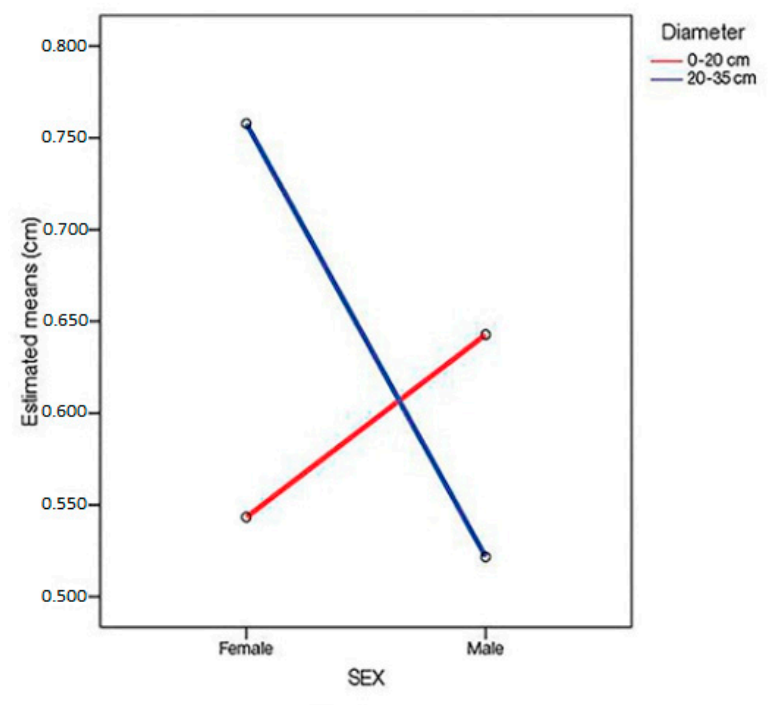

(a)

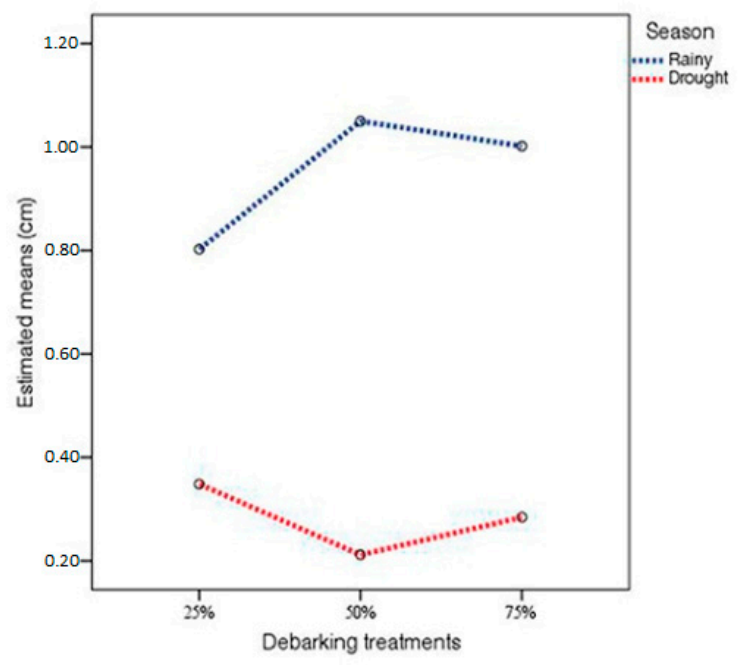

(b)

Figure 3. Post hoc test of the significative interactions associated with Amphipterygium adstringens bark thickness regeneration capacity (cm). (a) Differences between sexes (females vs. males) and diameter categories (DBH $\leq 20 \mathrm{~cm}$ vs. DBH $\geq 20.1 \mathrm{~cm}$ ). (b) Differences among debarking intensity treatments $(2 \times 25 \% ; 2 \times 50 \%$ and $2 \times 75 \%)$ and debarking seasons (wet and dry). 


\subsection{Survival Rate of Amphipterygium adstringens}

Of the 72 debarked trees, $86.1 \%$ survived during the two years after bark removal. Those that died did so during the dry season rather than in the wet season ( 6 vs. 4 individuals, respectively), particularly female trees $(n=6)$. In fact, the tolerance of the trees debarked in the wet season was also observed over time: eight months after harvesting the first dead individual was recorded, whereas for the trees debarked during the dry season, the first mortality occurred only two months after harvesting. In both cases, these were female trees. There was a significant (but negative) interactive effect between season (dry) and $50 \%$ debarking treatment $(p=0.012)$ on the survival of the harvested individuals (Table 3).

Table 3. Results of a generalized linear model to test effects of variables associated with the survival of experimentally debarked Amphipterygium adstringens trees.

\begin{tabular}{|c|c|c|c|c|c|c|}
\hline & Coefficient & Standard Error & Lower Limit (95\%) & Upper Limit (95\%) & $X^{2}$ & $p$ Value \\
\hline Intercept & 0.845 & 1.087 & -1.019 & 3.277 & 0.767 & 0.381 \\
\hline Season (dry) & 1.892 & 1.749 & -1.125 & 8.845 & 1.368 & 0.242 \\
\hline Sex (male) & 0.584 & 1.422 & -2.188 & 3.681 & 0.185 & 0.667 \\
\hline Diameter $(\geq 20 \mathrm{~cm})$ & 0.584 & 1.422 & -2.188 & 3.681 & 0.185 & 0.667 \\
\hline Treatment $(50 \%)$ & 0.793 & 1.675 & -2.368 & 5.842 & 0.241 & 0.624 \\
\hline Treatment $(75 \%)$ & 0.075 & 1.442 & -2.898 & 2.939 & 0.003 & 0.956 \\
\hline Season (dry):Sex (male) & -0.039 & 1.602 & -6.039 & 3.993 & 0 & 0.985 \\
\hline Season (dry):Diameter $(\geq 20 \mathrm{~cm})$ & -0.039 & 1.602 & -6.039 & 3.993 & 0 & 0.985 \\
\hline Season (dry): Treatment 50\% & -4.424 & 2.093 & -12.586 & -0.832 & 6.258 & 0.012 \\
\hline Season (dry): Treatment 75\% & -2.363 & 1.75 & -8.013 & 0.739 & 2.166 & 0.141 \\
\hline Sex (male):Diameter $(\geq 20 \mathrm{~cm})$ & -2.041 & 1.361 & -4.789 & 0.477 & 2.528 & 0.112 \\
\hline Sex (male):Treatment (50\%) & 1.448 & 1.991 & -3.314 & 8.481 & 0.365 & 0.546 \\
\hline Sex (male):Treatment (75\%) & 0.821 & 1.751 & -3.307 & 6.371 & 0.178 & 0.673 \\
\hline Diameter $(\geq 20 \mathrm{~cm})$ :Treatment $(50 \%)$ & 1.448 & 1.991 & -3.314 & 8.481 & 0.365 & 0.546 \\
\hline Diameter $(\geq 20 \mathrm{~cm}):$ Treatment $(75 \%)$ & 0.821 & 1.751 & -3.307 & 6.371 & 0.178 & 0.673 \\
\hline
\end{tabular}

Likelihood ratio test $=12.121$ with 14 degrees of freedom; $p=0.5965, n=72$.

\section{Discussion}

\subsection{Bark Regeneration and Tolerance of A. adstringens after Debarking}

Amphipterygium adstringens bark regeneration process occurred mainly over damaged functional xylematic tissue (thickness regeneration), and only rarely on the vascular cambium located in the edge of the harvest wound (lateral regeneration). This finding is opposite to the pattern of regeneration most commonly documented across the tropics in both tropical dry and wet forests, for various tree species, in which wound closure generally starts from the edges [47-49], and subsequently is combined with regeneration of bark thickness $[14,18]$.

In the montane southern Cape forests of South Africa [47], the differences in the regeneration process observed at the levels of species and individuals are associated with the intensity of tissue damage and the cutting season. In that context, lateral regeneration is associated with more extensive and deeper damage during the dry season, whereas regeneration in thickness occurs under superficial peelings carried out during the wet season [16]. Based on those observations, a greater proportion of lateral regeneration in A. adstringens was expected; nonetheless, $98.6 \%$ of the trees regenerated their bark in thickness regardless of the cutting season, and only $1.39 \%$ (one individual) showed lateral regeneration. Other studies $[6,40,50]$, have suggested that response to mechanical bark damage could be determined by a balance among environmental, physiological and phylogenetic constraints that influence anatomical compartmentalization mechanism of the bark and wood of each species [51-54]. In fact, recent research has shown similar patterns of regeneration as that observed for A. adstringens. Geldenhuys et al. [55] found that 17 of 22 tree species in montane forests in South Africa had low or no lateral growth of the bark; as well as Delvaux et al. [5], who demonstrated that only 2 of 12 tree-stripped tree species in the dry forests of Benin, Africa, completely regenerated the wound laterally. In the same 
way, Baldauf and Maës dos Santos [16] found that $99 \%$ of the individuals of H. drasticus in Brazil Cerrado forests regenerated the bark only in thickness.

Particularly for A. adstringens, Orduño [36] showed that there are differences in the regeneration process according to the depths of the cut, suggesting that callus formation in surface damage (without damage to the vascular cambium) originates from the cells present in the inner bark (radial and axial parenchyma, and the sheath of the canals), and that the new periderm is formed 20 days after bark removal; whereas in the deep damage (removing outer and inner bark) this occurs up to 102 days and is generated from the remnant cambium located at the edges of the wounds and the axial and radial parenchyma present in areas close to the cambium. So even though the regeneration of the bark of A. adstringens was five times faster in the surface damage, this species was also able to close the wounds before a deep damage, as we demonstrate in the present research.

In fact, as proposed by Zimmermann and Brown [56] and Stobbe et al. [52] in dry conditions and under cellular stress after debarking, the callus originates from remnants of cambium located in the periphery of the wound, and new cambium is generated from the existing undamaged vascular cambium; as demonstrated by Orduño [36] during the process of cellular compartmentalization of $A$. adstringens. In contrast, some authors [51,57] have also suggested that after debarking some temperate species are able to form callus relatively quickly and uniformly if there is proliferation of radial cells in the xylem, even when the vascular cambium and the associated phloem have been completely removed, as is the case of all the treatments performed in this study for $A$. adstringens. These observations suggest that $A$. adstringens is highly tolerant to debarking, and therefore is feasible to harvest of a larger volume of bark per individual without compromising its physiological integrity.

The high bark regeneration capacity observed in A. adstringens, even when the vascular cambium was removed, had only been observed in a limited number of species worldwide [15,58]. Part of this group of species, Adansonia digitata L., exhibits a mechanism of cellular compartmentalization similar to that of $A$. adstringens [59], which positively impacts on a high rate of survival and regeneration [60], as reported in the present study. In contrast, most medicinal bark species in the world have mortality rates close to $100 \%$ and much slower bark regeneration when harvest involves the removal of the vascular cambium $[47,50,55,61]$. Arguably, the high tolerance displayed by A. adstringens may be due to the combination of various physiological, morphological and anatomical factors of the bark [62]. That is, this species has an outer $(10-20 \mathrm{~mm})$ and inner $(4-6 \mathrm{~mm})$ thick bark with high exudate production, as well as abundant axial parenchyma in the xylem [36]. Those same attributes have been related to the efficient regeneration of seven species of the Bolivian Amazon [50]. For 12 species in Benin's tropical dry forests, the thickness of the phloem conduction area (cribrous tubes and axial parenchyma) is one of the most important variables that influence wound closure [63]. According to Orduño [36] A. adstringens reportedly has a large phloem conduction area.

Another interesting aspect associated with the tolerance of this species refers to the post-debarking anatomical response. According to Delvaux et al. [40], after the experimental harvest to xylem of 12 tropical tree species from Benin, West Africa, all had pores of smaller area compared with non-debarked trees, but they increased their density, a process that influenced the decrease in the specific conductivity area for $80 \%$ of the taxa and, consequently, reduced tissue production for wound closure. Another study has shown for $A$. adstringens differences in wood anatomy between sexes, where female trees have both greater wood density and pore diameter, and a higher hydraulic conductivity index than male trees [64].

Following Delvaux et al. [40], it is likely that the anatomical features of the wood in the female individuals of $A$. adstringens confer the ability to regenerate the wounds more quickly compared to the male trees because they contribute a greater flow of water and nutrients through the functional xylem. Moreover, due to the organization of the pores (multiple), the female trees also present alternate routes for conduction, conferring security 
to them by avoiding local embolisms [64]. Consequently, this finding emphasizes the need to analyze the life histories of each sex in dioecious species subject to commercial debarking because they show differential responses with respect to the capacity of bark regeneration.

Despite $A$. adstringens high debarking tolerance, during the two years of our study no individual regenerated $100 \%$ of the pre-harvest bark thickness; this trend has been observed in other studies on commercial debarking worldwide [14,47-50,65]. Our study documented the dramatic impact of harvest season on A. adstringens bark regeneration, that is, wet season debarking allowed a much faster recovery. Extrapolated from the average percent of bark regeneration and tree wound depth, we estimate that the bark of $A$. adstringens trees (regardless their sex) would take around three years to fully regenerate if debarked during the wet season, contrasting with the five years required for a dry season harvested tree.

Our estimated time for full bark regeneration for $A$. adstringens is low compared with other tropical dry forest species. In the case of Himatanthus drasticus (Mart.) Plumel (Apocynaceae) [16], a five-year recovery period was proposed for dry season debarking and 6.5 years for wet season debarking (considering a bark regeneration rate of $0.32 \pm 0.09 \mathrm{~cm}$ year $^{-1}$ ). In contrast, our result is two to 15 times lower with respect to the regeneration gradient proposed by Delvaux et al. [6] for five tropical species, whose regeneration rates range from 1.7 to $15.8 \mathrm{~cm}_{\text {year }}{ }^{-1}$.

The differences in the bark regeneration process observed for $A$. adstringens and the patterns described elsewhere $[7,47,50]$ raise the need to situate such responses in the context of physiological trade-offs and as part of a functional spectrum of debarking responses.

\subsection{Factors That Affect Bark Regeneration of A. adstringens}

In this study we present a coupled two-way interaction between cutting season:debarking treatment and sex:diameter category, both of which have a positive effect on $A$. adstringens bark regeneration. These results contrast with other studies because these only analyzed the simple effect of some variables (tree diameter, debarking treatment, cutting season, light intensity, site quality) over the bark regeneration capacity $[5,6,13,14,16,17]$, with some exceptions $[48,61]$. Observed interactions indicate $A$. adstringens bark regeneration can be improved by harvesting during the wet season at a 50\% harvest intensity treatment. Furthermore, $A$. adstringens also shows higher regeneration rates for wet season debarked large diameter $(\mathrm{DBH} \geq 20.1 \mathrm{~cm})$ female trees.

In relation to the influence of precipitation on bark regeneration, other research has shown that bark regeneration is not correlated with landscape moisture gradients $[13,14,54]$, whereas others indicate that dry conditions stimulate this process $[16,18]$. As we indicated previously, debarking of $A$. adstringens trees during the wet season positively influenced the wounds closure of both sexes, similar to the results of Solares et al. [19] for the same species, as well as those of Delvaux et al. [39] for five tropical trees in Africa. In fact, it has been suggested that conserving moisture from the exposed surface is the main factor for successful regeneration [56,57,61]. For the temperate forest tree Tilia sp. [52], debarking during wet season (vegetative period) increases the rate of regeneration due a greater proportion of undifferentiated xylem on the surface of the wound, which will form the callus, as well as high concentrations of indoleacetic and abscisic acids that participate in the cellular processes of regeneration [53].

For a deciduous tropical species like $A$. adstringens, even though its foliation begins with the first rains [66] and radial growth occurs after foliar expansion, this species allocates resources for wound closure in synchrony with growth, contrary to that observed by Delvaux et al. in Benin [40]. This may be due to the vascular cambium reactivation and to a greater metabolic activity during the rains, which increases the photosynthates flow toward the damaged areas $[56,63]$. Thus, the high tolerance of $A$. adstringens is possibly explained by the life strategies that it presents (fast growth and demand for light), similar to those of Khaya senegalensis (Desr.) A. Juss., one of the most tolerant species recorded in the international literature [40]. Consequently, these intrinsic characteristics could be 
associated with a phylogenetic factor, given that other species of the Sapindales, including those of Anacardiaceae family, also show a good rate of regeneration during the rainy season $[5,40,50,65]$.

Regarding the debarking prescriptions, although the intermediate treatment (50\% of the stem bole) was the best for $A$. adstringens bark regeneration in both sexes, the most intensive harvest followed in order of importance $(75 \%)$. These results agree with other investigations $[14,40,61]$ in which a positive correlation between the intensity of debarking and the regeneration rate was suggested, whereas Pandey and Mandal [18] and Mariot et al. [48] pointed to an opposite pattern. As Romero [58] suggested, it is feasible that after severe damage the hormonal activity stimulated by the physiological stress suffered by the plant will increase in order to restore hydraulic conductivity and close the wound as soon as possible, thus decreasing the risk of vulnerability to the attack of pests and diseases. In fact, adult trees with larger allometric dimensions have a better response to debarking $[40,54,55]$, as we recorded in the present study for $A$. adstringens; nonetheless, contrary to the hypothesis proposed, the findings of this study show that thicker female trees regenerate their bark better.

\subsection{Impact of Debarking on A. adstringens Survival}

In a study of 10 temperate trees [57], fast-growing species have a lower rate of wound regeneration, which has been related to a limited ability to produce exudates as a chemical defense against the attack of insects and pathogens [50,54]. Nonetheless, our results contradict these assumptions because, although $A$. adstringens is a pioneer species [64], it produced abundant quantities of latex and resins. The presence of these exudates has been related to increases in survival rates and bark regeneration $[15,60]$, which could partially explain the high tolerance and wound closure in A. adstringens, due to secretions that avoid infections and drying of the xylematic tissue, thus preventing possible cavitations [58].

This trend in bark regeneration is maintained even considering the effect of the sex factor, because, although the female trees of $A$. adstringens have a higher radial growth compared with the male ones [64], they also have the best regeneration rates. This result is contrary to that suggested by Guariguata and Gilbert [67] for six perennial and slowgrowing tropical tree species of Panama, who demonstrated that there is no relationship between growth and wound closure, but that there is a presence of latex and resins and an increase in the damage regeneration rate. Our finding also contradicts the statements of Delvaux et al. [5] and Geldenhuys et al. [55], who recorded a close negative correlation between wound closure and insect attack on medicinal tree species in Africa.

These differences in the behavior between species may be due to the fact that, at present, no global study on radial growth capacity, bark regeneration and chemical defense in tropical tree species has considered dioecism as an explanatory variable [7]. Nonetheless, in dioecious species, sex is a relevant variable and associated with distinct ecophysiological and reproductive strategies [68-70], which could affect the ability of survival and bark regeneration. Particularly for A. adstringens this distinction is critical because it shows trade-offs between sexes and within each sex. Thus, female trees have a higher rate of radial growth and bark regeneration even when they invest more resources in reproduction compared with male trees [64]; this is contrary to the suggestion of Monteiro et al. [13] for dioecious tree species. Nonetheless, it is important to highlight that female trees of A. adstringens also have the highest mortality rate, mainly due to the drill bug attacks (Olenosus serrimanus Bates and Lagocheirus obsoletus Thomson) during the dry season; so, it is inferred that the trees of this sex focus their energy on growing in thickness and healing damaged tissues rather than producing chemical defenses against an infestation.

It has been suggested that post-debarking mortality is due to the interruption of water and nutrient flow through the functional xylem and phloem [6,40,49], but our study seems to suggest that the physiological weakening of the trees as a result of debarking also generates a greater attraction of wood and bark-consuming insects that induce mortality, 
which have a greater impact on the female individuals of $A$. adstringens in the dry season, independent of the trees' diameter categories and the amount of bark removed.

These results support the approaches of previous studies developed with other tree species of medicinal importance [6,16,49], showing that although tree diameter does not affect survival, the bark thickness does influence this parameter. Nonetheless, it does not coincide with the amount of bark removed by tree, because there seems to be a tolerance gradient, where, on the one hand, partial debarking with machete favors the survival rate [49], whereas, on the other hand, the bark harvest from 50 to $100 \%$ of the stem bole shows a contrary pattern $[6,16]$. In consequence, results suggest both the capacity of bark regeneration as well as survival are dependent on the species [5] and individuals [61], and in the case of $A$. adstringens also the sex.

According to Romero [58] the decrease of exudates favors the invasion of pests and benefits the establishment of pathogens and fungi, which infest generally weak trees; but it has also been suggested that the defensive compounds of the host trees serve as precursors for attracting bark beetles of the opposite sex [71], increasing the damage rates. Furthermore, dry conditions generate changes in the population dynamics of insects and pathogens, a process that influences the mortality of some forest species, which, due to water stress conditions, are more susceptible to attack by these pests [72].

The prolonged dry season (six to eight months) of the tropical dry forests where A. adstringens grows is characterized by the reduction of water supply in the soil and the increase in evaporative demand [73]. These conditions in association with debarking during this time of year could alter their anatomical-physiological condition and affect survival. This would explain the negative coefficient of the cutting seasons:debarking treatments interactions obtained in the generalized linear model of the present study and would allow to establish that debarking $A$. adstringens trees during the dry season increases mortality, mainly due to a greater insect attack on trees weakened by the harvest. Furthermore, a similar pattern was observed in a natural non-harvested $A$. adstringens population of a total of 160 adult trees monitored for a four-year period where only seven trees died. All of those deceased trees were female, all of which died during dry season [63], hence suggesting the higher intrinsic vulnerability of female trees.

In general terms, Delvaux et al. [6] found in 12 tree species with medicinal bark from Benin that $69.4 \%$ of the 72 dead individuals (50\% of these between six and 18 months after harvest) were debarked over the rainy season, whereas post-debarking mortality during the dry season was twice as low. These results contrast with the response of $A$. adstringens, a species that presented a $23.9 \%$ mortality rate at two years of the study, $60 \%$ of which occurred in the dry season during the first six months after debarking.

We believe that functional approaches can provide further insights to understand species responses to debarking beyond individual case studies [62]. Evidence suggests that TDF trees display two contrasting functional strategies that are associated with coping with water stress and physical damage. In these forests, dense wooded species tend to have thin bark and high resprouting capacity, while soft wooded species more often have thick barks, but limited resprouting capacity [74]. Existing ethnobotanical and forest management data on bark harvest may be reinterpreted within species functional strategies. For example, two highly demanded medicinal bark species harvested in Mexican TDFs display these contrasting strategies. Hintonia latiflora belongs to the first group of resprouting species [20,64], whereas A. adstringens strategy includes a thick bark and resin as a mechanism to recover from damage. Such responses clearly set the management strategies available for sustaining the harvest of those species.

\subsection{Sustaining Medicinal Barks: Challenges and Opportunities}

Our results point toward some seemingly simple sets of management recommendations that contribute to sustain the harvest of $A$. adstringens bark:wet season harvesting, applying a $50 \%$ debarking intensity and targeting large diameter female trees. Despite the apparent simplicity of our recommendations, when coupled with the body of ecologi- 
cal $[23,39,64]$ and pharmacological evidence $[23,32-34]$, as well as contrasted with current bark harvest practices and a complex socio-ecological reality, setting management guidelines is less straightforward. In this section we intend to discuss and bridge contrasting evidence across disciplines and local realities, focusing on two general dimensions: which trees can be targeted for harvest (selection) and how trees can be harvested (practices).

Sex differences in bark regeneration and survival are important findings but less obvious is how they should be incorporated in management decisions. Traditional harvest tends to target trees with redder bark, a trait associated with female trees. Preferential harvest of female trees results in disproportionately male tree populations and limited population regeneration [64]. Sexes not only differ in their ecological responses, but they also have some phytochemical differences characterized by a higher concentration of the triterpenic acids in the female individuals, this being the main difference recorded in the amount of masticadienonic acid, but also a major accumulation of $3 \alpha$-hydroxymasticadienonic and isomasticadienonic acids [32]; nevertheless, there is a lack of studies comparing the pharmacological efficacy of different sexes, necessitating further analyses.

Large diameter $(\mathrm{DBH}>20.1 \mathrm{~cm})$ A. adstringens trees regenerate bark faster than those with smaller diameters, but these larger trees are relatively rare. Reportedly, they represent $\sim 30 \%$ of the tree population [64]. Thus, harvests that only target the largest trees will significantly limit the harvestable bark, thus challenging the commercial viability of this activity in many locales. From the phytochemical point of view, there are no significant differences between masticadienonic acid concentration in different diameter (age) individuals [23].

How trees are debarked includes harvest seasonality, harvest intensity, and harvest practices, among other considerations. Debarking seasonality is key for sustaining bark harvests. As pointed out by Solares [39], wet season harvesting is desirable for bark regeneration but would require implementing new bark drying strategies. The current practice of leaving the recently harvested bark to dry in the forest floor would not serve this purpose in the moist conditions prevalent in the wet season, where there is a high risk of contamination by fungi. Seasonality of forest product harvest has also to be considered within diversified livelihood strategies characteristic of rural subsistence livelihoods [75,76]. Any change in harvest timing for medicinal barks implies an adaptation in timing of other livelihood activities. Additionally, during the dry season A. adstringens bark displays a slightly higher (but not significant) concentration of its main pharmacologically active compounds (masticadienonic and $3 \alpha$-hydroxymasticadienonic acids) [32], these marginal differences do not justify on pharmacological grounds harvesting in any particular season.

Our study concords with those of Solares $[19,23,39]$ indicating that the $50 \%$ debarking of individual trees is recommended as it maximizes bark regeneration and limits tree mortality, while allowing production. Considering the observed rates, we expect that it will take three years for a tree to fully regenerate its bark if debarked during the wet season, and five years if harvested during the dry season.

Preliminary evidence suggests that the bark from the first harvest displays some phytochemical differences with the post-harvest regenerated bark of $A$. adstringens (resulting from a second harvest). The regenerated bark produces larger amounts of triterpenic acids, being an excellent source of active compounds; although the volume of plant material may be lower, the masticadienonic acid concentration gives it a higher quality and probable pharmacological efficacy [23]. In any case, the market acceptance of the regenerated bark still needs to be tested and arguably promoted $[7,15]$. Even if the regenerated bark cannot be marketed, securing tree survival is desirable. At $50 \%$ harvest intensity, the other $50 \%$ of the original bark can be extracted in a second harvest, and the tree can then be left unharvested to reproduce and contribute to the demographic viability of the population. As a precautionary measure, under Mexico's official forestry guidelines NOM 005 RECNAT 1997 [77], 20\% of the adult trees are required to be left unharvested. Limits to harvest intensity can pose a serious challenge to the bark extraction viability in forests with low A. adstringens densities. Arguably in these contexts, additional silvicultural practices including propagation would be necessary to sustain bark harvest. 
Our experimental approach demonstrated that relatively simple debarking practices (i.e., long strip debarking), like those traditionally practiced, under some conditions can contribute to sustainable $A$. adstringens bark harvests. The more complex practices recommended by Solares [39], which require a precise control of the depth of bark removal, a laborious domino pattern of bark extraction, and protecting the wound with a plastic cover, may potentially further improve bark regeneration and tree survival. However, we believe that those practices imply additional labor, are less readily applicable, and imply reducing harvestable bark more than the practices considered here. Another practice that deserves additional consideration is superficial debarking, which apparently reduces the harvest volume per tree but increases bark regeneration rates [36].

Medicinal bark harvest rarely is the only disturbance in these TDFs to other land uses, which often interact with bark harvests across the landscape, influencing their sustainability. In this and neighboring regions, livestock (generally cattle or goats) are allowed to freely range the TDF, particularly during the wet season. Experimental evidence in our study site shows that cattle ranching coupled with other disturbances limits forest post-disturbance recovery [78,79] and can eliminate $A$. adstringens regeneration [64]. Thus, developing management practices that minimize the conflict of use between these activities are essential to sustain these and other forest products.

Climate change and climate variability can significantly influence the demographic dynamics of $A$. adstringens populations. Lower precipitation is associated with reduced $A$. adstringens regeneration and overall population growth rates [64]. How climate change interacts with bark harvests still need to be fully explored. Reduced precipitation can change the potential distribution of this species.

While we believe that management strategies should be tailored to local contexts [80], as a general approach we recommend focusing on improving how bark is harvested, rather than targeting only a small subset of the $A$. adstringens population (i.e., large diameter female trees) that at the individual level may display higher regeneration rates but that can represent a limited supply and may negatively impact demographic dynamics. In addition, but beyond the scope of this paper, lie other aspects critical for sustaining medicinal barks, including the evolving role of well-established medicinal plant trade networks in driving the extraction of medicinal plants at larger scales $[26,81,82]$ as well as the role of local governance and land tenure arrangements defining the access to these medicinal resources $[1,8,9,80]$.

\section{Conclusions}

Our experimental approach showed that $A$. adstringens trees respond well to deep debarking, that is, when bark extraction damage includes the functional secondary xylem. For experimentally debarked $A$. adstringens trees, bark regeneration and survival were maximized when practiced during the wet season at intermediate debarking intensities. Large diameter category $(\geq 20.1 \mathrm{~cm})$ trees responded particularly well to debarking, as they showed the highest bark regeneration and survival rates.

Our results suggest that sex is a more complex factor in the response of this dioecious species to debarking, as female trees displayed higher bark regeneration rates but lower survival than males. Differences in responses to bark damage between the sexes can be associated with differences in wood anatomy [64].

Despite potential implementation challenges, we believe that wet season harvesting, and 50\% debarking intensities are recommendations that can significantly improve the sustainability of bark harvests in most contexts. Regarding the quality of plant material, associated with its phytochemical composition and pharmacological efficacy, the few studies available related to sexes, seasons [32] and management regimens [23] indicated a higher amount of active compounds in female individuals but not enough to choose a differential gather. As for the harvesting season, it does not represent a decisive factor related to main constituent concentration, and perhaps the most influential aspect is the post-harvest exploitation, being that the regenerated bark is a highly concentrated source 
of bioactive compounds. An integrated strategy for sustaining A. adstringens bark harvests would need to consider both the individual tree responses explored here, as well as the demographic implications of debarking and interaction with other land uses across the landscape. All in all, our results are part of a sound ecological basis that can inform and dialogue with local strategies to sustain $A$. adstringens bark harvests.

Author Contributions: Conceptualization, L.B.-R. and J.I.V.-H.; methodology, L.B.-R., J.I.V.-H., A.R.M., M.L.-C. and G.Á.-P.; software, A.S.-V. and M.L.-C.; validation, L.B.-R., J.I.V.-H., B.M.-A. and E.P.H.; formal analysis, A.S.-V. and L.B.-R.; investigation, L.B.-R., J.B., M.A.B.d.l.R. and E.P.-H.; resources, J.B.; data curation, A.S.-V., G.Á.-P., B.M.-A. and L.B.-R.; writing-original draft preparation, L.B.-R. and J.A.S.-H.; writing-review and editing, L.B.-R., J.A.S.-H., S.C., A.M.-B., A.R.-M., M.A.B.d.1.R., G.Á.-P., T.T. and R.B.; visualization, J.I.V.-H.; supervision, L.B.-R. and J.I.V.-H.; project administration, J.I.V.-H.; funding acquisition, J.B. All authors have read and agreed to the published version of the manuscript.

Funding: This research was funded by the National Council of Science and Technology of Mexico [grant number 265032], and the Colegio de Postgraduados (COLPOS). Also, we appreciate the contribution of the CONACYT Thematic Network "Non-Timber Forest Products: Contributions from Ethnobiology for their Sustainable Use" (Projects \#271837, 280901, 293914), and the project "Ecological and Cultural Strategies of Traditional Peoples to face uncertainty in the availability of Plant Resources" (PROMEP-UAEMOR-PTC-342).

Institutional Review Board Statement: "Not applicable" for studies not involving humans or animals.

Informed Consent Statement: “Not applicable” for studies not involving humans.

Data Availability Statement: The data presented in this study are available on request from the corresponding author. The data are not publicly available due to privacy restrictions.

Acknowledgments: The first author would like to thank the Postdoctoral Fellow Program of the Dirección General de Personal Académico, UNAM, for a fellowship that allowed him to work in this project. This manuscript is dedicated to the memory of Javier Caballero.

Conflicts of Interest: The authors declare no conflict of interest.

\section{References}

1. Shackleton, S.; Shackleton, C.; Shanley, P. Non-Timber Forest Products in the Global Context, 1st ed.; Tropical Forestry Series; Springer: Berlin/Heidelberg, Germany, 2011. [CrossRef]

2. Ticktin, T. The ecological sustainability of non-timber forest product harvest: Principles and methods. In Ecological Sustainability for Non-Timber Forest Products. Dynamics and Case Studies of Harvesting, 1st ed.; Shackleton, C., Pandey, A., Ticktin, T., Eds.; People and Plants International-Conservation Series; Routledge: London, UK, 2015; Chapter 3, pp. 31-53. [CrossRef]

3. Ticktin, T. The ecological implications of harvesting non-timber forest products. J. Appl. Ecol. 2004, 41, 11-21. [CrossRef]

4. Hall, P.; Bawa, K. Methods to assess the impact of extraction of Non-Timber Tropical Forest Products on Plant Populations. Econ. Bot. 1993, 47, 234-247. [CrossRef]

5. Delvaux, C.; Sinsin, B.; Darchambeau, F.; Van Damme, P. Recovery from bark harvesting of 12 medicinal tree species in Benin, West Africa. J. Appl. Ecol. 2009, 46, 703-712. [CrossRef]

6. Delvaux, C.; Sinsin, B.; Van Damme, P. Impact of season, stem diameter and intensity of debarking on survival and bark re-growth pattern of medicinal tree species, Benin, West Africa. Biol. Conserv. 2010, 143, 2664-2671. [CrossRef]

7. Cunningham, A.; Campbell, B.; Luckert, M. Bark: Use, Management, and Commerce in Africa. Adv. Econ. Bot. 2014, 17, 1-288.

8. Blancas, J.; Caballero, J.; Beltrán-Rodríguez, L.; Cortés, L. Non-Timber Forest Products of Mexico: An Overview, 1st ed.; Thematic Network Non-Timber Forest Products of the National Council of Science and Technology (CONACYT No. 280901); CONACYT: Mexico City, Mexico, 2017.

9. Beltrán-Rodríguez, L.; Cristians, S.; Sierra-Huelsz, A.; Blancas, J.; Maldonado-Almanza, B.; Bye, R. Barks as Non-Timber Forest Products in Mexico: National Analysis and Recommendations for their Sustainable Use, 1st ed.; Instituto de Biología, Universidad Nacional Autónoma de México (UNAM): Mexico City, Mexico, 2020; ISBN 978-607-30-4054-9.

10. Fierro, A.; Guerrero, C.; Hersch-Martínez, P.; Pérez, A. Some commercially important wild medicinal barks from the tropical deciduous forests in the Balsas River Basin: Effect of the harvest on its population density. In Agroforestry Systems in Latin America and the Tropical Deciduous Forest in Mexico, 1st ed.; Monroy, R., Colín, H., Boyas, C., Eds.; National Institute of Forestry, Agricultural and Livestock Research (INIFAP): Mexico City, Mexico; Autonomous University of the Morelos State (UAEM): Cuernavaca, Mexico, 2000; pp. 533-541. 
11. Linares, E.; Bye, R. Traditional Markets in Mesoamerica: A Mosaic of History and Traditions. In Ethnobotany of Mexico: Interactions of Peoples and Plants in Mesoamerica, 1st ed.; Lira, R., Casas, A., Blancas, J., Eds.; Springer: New York, NY, USA, 2016; Chapter 7, pp. 151-178. [CrossRef]

12. Beltrán-Rodríguez, L.; Manzo-Ramos, F.; Maldonado-Almanza, B.; Martínez-Ballesté, A.; Blancas, J. Wild Medicinal Species Traded in the Balsas Basin, Mexico: Risk Analysis and Recommendations for Their Conservation. J. Ethnobiol. 2017, 37, 743-764. [CrossRef]

13. Monteiro, J.; Lins, E.; de Lima, E.; Amorim, E.; Albuquerque, U. Bark regeneration and tannin content in Myracrodruon urundeuva Allemão after simulation of extractive damages-Implications to management. Environ. Monit. Assess. 2011, 180, 31-39. [CrossRef]

14. Soares, I.; Sobral, A.; Monteiro, J.; Lima, E.; Albuquerque, U. Impact of collection on bark regeneration from Stryphnodendron rotundifolium Mart. in northeastern Brazil. Environ. Monit. Assess. 2017, 189, 234. [CrossRef]

15. Cunningham, A.; Mbenkum, F. Sustainability of Harvesting Prunus Africana Bark in Cameroon: A Medicinal Plant in International Trade, 1st ed.; People and Plants; UNESCO: Paris, France, 1993.

16. Baldauf, C.; Maës dos Santos, F. The effect of management systems and ecosystems types on bark regeneration in Himatanthus drasticus (Apocynaceae): Recommendations for sustainable harvesting. Environ. Monit. Assess. 2014, 186, 349-359. [CrossRef] [PubMed]

17. Biggs, A. Phellogen regeneration in injured peach tree Bark. Ann. Bot. 1986, 57, 463-470. [CrossRef]

18. Pandey, A.; Mandal, A. Sustainable Harvesting of Terminalia arjuna (Roxb.) Wight \& Arnot (Arjuna) and Litsea glutinosa (Lour.) Robinson (Maida) Bark in Central India. J. Sustain. Forest. 2012, 31, 294-309. [CrossRef]

19. Solares, F.; Jasso, J.; Vargas-Hernández, J.; Soto, M.; Rodríguez, C. Regeneration capacity in lateral thickness and in crust of Cuachalalate (Amphipterygium adstringens Schiede ex Schlect.) in the Morelos State. Ra Ximhai 2006, 2, 481-495. [CrossRef]

20. Beltrán-Rodríguez, L.; Romero-Manzanares, A.; Luna-Cavazos, M.; García-Moya, E. Architectural and morphological variation of Hintonia latiflora (Rubiaceae) in relation to bark harvest and environmental factors. Rev. Biol. Trop. 2017, 65, 900-916. [CrossRef]

21. Solares, F.; Vázquez-Alvarado, J.; Gálvez-Cortés, M. Commercialization channels of cuachalalate (Amphipterigium adstringens Schiede ex Schlecht.) bark in Mexico. Rev. Mex. Cienc. For. 2012, 3, $29-42$.

22. Da Silva, J.; da Silva, L.; Albuquerque, U.; Cardoso, C. Bark and latex harvesting short-term impact on native tree species reproduction. Environ. Monit. Assess. 2018, 190, 744. [CrossRef]

23. Solares, F. Bark Regeneration Capacity and Phytochemical Evaluation before and after Debarking in Cuachalalate. Master's Thesis, Colegio de Postgraduados Campus Montecillo, Texcoco, Mexico, 1995.

24. García, E. Modificaciones al Sistema de Clasificación Climática de Köppen (para Adaptarlo a las Condiciones de la República Mexicana), 16th ed.; Instituto de Geografía, Universidad Nacional Autónoma de México: Ciudad de México, Mexico, 2004.

25. Servicio Meteorológico Nacional. Datos climáticos. Departamento de información estadística. Comisión Nacional del Agua. Available online: https://smn.conagua.gob.mx/es/informacion-climatologica-por-estado?estado=mor (accessed on 18 May 2014).

26. Beltrán-Rodríguez, L.; Valdez-Hernández, J.; Luna-Cavazos, M.; Romero-Manzanares, A.; Pineda-Herrera, E.; MaldonadoAlmanza, B.; Borja de la Rosa, M.; Blancas-Vázquez, J. Structure and tree diversity of secondary deciduous tropical forests in the Sierra de Huautla Biosphere Reserve, Morelos. Rev. Mex. Biodivers. 2018, 89, 108-122. [CrossRef]

27. Durand, L. Pensar positivo no basta. Actitudes en torno a la conservación en la Reserva de la Biosfera Sierra de Huautla, México. Interciencia 2010, 35, 430-436.

28. López-Medellín, X.; Vázquez, L.; Valenzuela-Galván, D.; Wehncke, E.; Maldonado-Almanza, B.; Durand-Smith, L. Percepciones de los habitantes de la Reserva de la Biósfera Sierra de Huautla: Hacia el desarrollo de nuevas estrategias de manejo participativo. Interciencia 2017, 42, 8-16.

29. Abad-Fitz, I.; Maldonado-Almanza, B.; Aguilar-Dorantes, K.; Sánchez-Méndez, L.; Gómez-Caudillo, L.; Casas, A.; Blancas, J.; García-Rodríguez, Y.; Beltrán-Rodríguez, L.; Sierra-Huelsz, J.; et al. Consequences of traditional management in the production and quality of copal resin (Bursera bipinnata Moc. \& Sessé ex DC.) Engl.) in Mexico. Forests 2020, 11, 991. [CrossRef]

30. Cuevas, X. A revision of the genus Amphipterygium (Julianiaceae). Ibugana 2005, 13, $27-47$.

31. Argueta, A. Atlas de las Plantas de la Medicina Tradicional Mexicana, 1st ed.; Instituto Nacional Indigenista: Ciudad de México, México, 1994.

32. Olivera, A.G.; Soto, M.; Martínez, M.; Terrazas, T.; Solares, F. Phytochemical study of cuachalalate (Amphiptherygium adstringens Schiede ex Schlecht). J. Ethnopharmacol. 1999, 68, 109-113. [CrossRef]

33. Oviedo-Chavez, I.; Ramírez-Apan, T.R.; Soto-Hernández, M.; Martínez-Vázquez, M. Principles of the bark of Amphipterygium adstringens (Julianaceae) with anti-inflammatory activity. Phytomedicine 2004, 11, 436-445. [CrossRef] [PubMed]

34. Navarrete, A.; Mata, R. Monografía Científica de Plantas Medicinales de México. Cuachalalate-Amhipterygium adstringens-. Pruebas de Control de Calidad (Identidad y Composición), Eficacia y Seguridad, 1st ed.; Sentido Giratorio: Ciudad de México, Mexico, 2009.

35. Comisión Permanente de la Farmacopea de los Estados Unidos Mexicanos. Farmacopea Herbolaria de los Estados Unidos Mexicanos, 2nd ed.; Secretaría de Salud: Ciudad de México, Mexico, 2013.

36. Orduño, A. Bark Anatomy of Four Species of the Tropical Deciduous Forest of the State of Morelos: Origin, Development and Regeneration. Master's Thesis, Colegio de Postgraduados Campus Montecillo, Texcoco, Mexico, 1998.

37. Hersch-Martínez, P. Destino Común: Los Recolectores y su Flora Medicinal. El Comercio de Flora Medicinal Silvestre Desde el Suroccidente Poblano, 1st ed.; Instituto Nacional de Antropología e Historia: Ciudad de México, Mexico, 1999. 
38. Rodríguez, T. Management and Conservation of Commercial Medicinal Plants in the Municipality of Copalillo, Guerrero. Master's Thesis, Universidad Nacional Autónoma de México, Ciudad de México, Mexico, 2003.

39. Solares, F.; Gálves, M. Manual para una Producción Sustentable de Corteza de Cuachalalate (Amphipterygium Adstringens Schiede ex Schlecht); Instituto Nacional de Investigaciones Forestales, Agrícolas y Pecuarias (INIFAP): Zacatepec, Morelos, 2002.

40. Delvaux, C.; Sinsin, B.; Van Damme, P.; Beeckman, H. Wound reaction after bark harvesting: Microscopic and macroscopic phenomena in ten medicinal tree species (Benin). Trees 2010, 24, 941-951. [CrossRef]

41. Mead, R.; Curnow, R.; Hasted, A. Statistical Methods in Agriculture and Experimental Biology, 2nd ed.; Springer Science \& Business Media: New Delhi, India, 1993.

42. Stemmler, M. Person-Centered Methods: Configural Frequency Analysis (CFA) and Other Methods for the Analysis of Contingency Tables, 1st ed.; Springer: Cham, Switzerland, 2014.

43. IBM Corp Released. IBM SPSS Statistics for Windows; Version 21.0; IBM Corp: New York, NY, USA, 2012.

44. Agresti, A. An Introduction to Categorical Data Analysis, 2nd ed.; John Wiley \& Sons, Inc.: New Jersey, NJ, USA, 2007.

45. Firth, D. Bias reduction, the Jefreys prior and GLIM. In Advances in GLIM and Statistical Modelling, 1st ed.; Fahrmeir, L., Francis, B., Gilchrist, R., Tutz, G., Eds.; Springer: New York, NY, USA, 1992; pp. 91-100.

46. R Core Team. R: A Language and Environment for Statistical Computing; R Foundation for Statistical Computing: Vienna, Austria, 2017.

47. Vermeulen, W.; Geldenhuys, C. Experimental Protocols and Lessons from Strip Harvesting of Bark for Medicinal use in the Southern Cape Forests; Wild Resources Limited FRP-DFID Project R8305 Report; Department for International Development: London, UK, 2004.

48. Mariot, A.; Mantovani, A.; Dos Reis, M. Bark harvesting systems of Drymis brasiliensis Miers in the Brazilian Atlantic Rainforest. Ann. Acad. Bras. Cienc. 2014, 86, 1315-1326. [CrossRef] [PubMed]

49. Guedje, N.; Tchamou, N.; Lejoly, J. Tree response to bark harvest: The case of a medicinal species, Garcinia lucida, as source of raw materials for plant-based drug development. J. Appl. Biosci. 2016, 99, 9476-9491. [CrossRef]

50. Romero, C.; Bolker, B. Effects of stem anatomical and structural traits on responses of stem damage: And experimental study in the Bolivian Amazon. Can. J. For. Res. 2008, 38, 611-618. [CrossRef]

51. Shigo, A. Compartmentalization: A conceptual framework for understanding how trees grow and defend themselves. Annu. Rev. Phytopathol 1984, 22, 189-214. [CrossRef]

52. Stobbe, H.; Schmitt, U.; Eckstein, D.; Dujesiefken, D. Developmental stages and fine structure of surface callus formed after debarking of living Lime Trees (Tilia sp.). Ann. Bot. 2002, 89, 773-782. [CrossRef] [PubMed]

53. Mwange, K.; Hou, H.; Cui, K. Relationship between endogenous indole-3acetic acid and abscisic changes and bark recovery in Eucommia ulmoides Oliv. after girdling. J. Exp. Bot. 2003, 54, 1889-1907. [CrossRef]

54. Ngubeni, N.; Jacobs, S.; Seydack, A.; Vermeulen, W.; Sass, G.; Seifert, T. Trade-off relationships between tree growth and defense: A comparison of Ocotea bullata and Curtisia dentata following bark harvesting in an evergreen moist South African Forest. Trees 2017, 31, 339-348. [CrossRef]

55. Geldenhuys, C.; Syampungani, S.; Meke, G.; Vermeulen, W. Response of different species to bark harvesting for traditional medicine in Southern Africa. In Multiple use Management of Natural Forests and Woodlands: Policy Refinement and Scientific Progress, 1st ed.; Bester, J., Seydack, A., Vorster, T., Van der Merwe, I., Dzivhani, S., Eds.; Department of Water Affairs and Forestry: Pretoria, South Africa, 2007; pp. 55-62.

56. Zimmermann, M.; Brown, C. Trees: Structure and Function, 1st ed.; Springer: New York, NY, USA, 1971.

57. Neely, D. Wound closure rates on trees. Arboric. Urban For. 1988, 14, 250-254.

58. Romero, C. Bark: Structure and Functional Ecology. Adv. Econ. Bot. 2014, 17, 5-26.

59. Fisher, J. Wound healing by exposed secondary xylem in Adansonia (Bombacaceae). IAWA Bull. 1981, 2, 193-199. [CrossRef]

60. Romero, C.; Dovie, D.; Gambiza, J.; Luoga, E.; Schmitt, S.; Grundy, I. Effect of commercial bark harvesting on Adansonia digitata (Baobab) in the Save-Odzi Valley, Zimbabwe, with considerations for its management. Adv. Econ. Bot. 2014, 17, 95-114.

61. Guedje, N.; Tchamou, N. Strategies towards sustainable bark sourcing as raw material for plant-based drug development: A case study on Garcinia lucida tree species. J. Appl. Biosci. 2017, 115, 11502-11512. [CrossRef]

62. Rosell, J. Bark in Woody Plants: Understanding the Diversity of a Multifunctional Structure. Integr. Comp. Biol. 2019, 59, 535-547. [CrossRef]

63. Delvaux, C.; Sinsin, B.; Van Damme, P.; Beeckman, H. Size of conducting phloem: The "key" factor for bark recovery of 12 tropical medicinal tree species. Flora 2013, 208, 111-117. [CrossRef]

64. Beltrán-Rodríguez, L. Structure, Population Dynamics and Bark Regeneration of Amphipterygium adstringens (Anacardiaceae) in the Ejido El Limón, Morelos, México. Ph.D. Thesis, Colegio de Postgraduados Campus Montecillo, Texcoco, Mexico, 2018.

65. Fasola, T.; Egunyomi, A. Bark extractivism and uses of some medicinal plants. Niger. J. Bot. 2002, 15, $26-36$.

66. Luna-Nieves, A.; Meave, J.; Morellato, L.; Ibarra-Manríquez, G. Reproductive phenology of useful seasonally dry tropical forest trees: Guiding patterns for seed collection and plant propagation in nurseries. For. Ecol. Manag. 2017, 393, 52-62. [CrossRef]

67. Guariguata, M.; Gilbert, G. Interspecific variation rates of trunk wound closure in a Panamanian Lowland Forest. Biotropica 1996, 28, 23-29. [CrossRef]

68. Bañuelos, M.J.; Obeso, J.R. Resource allocation in the dioecious shrub Rhamnus alpinus: The hidden costs of reproduction. Evol. Ecol. Res. 2004, 6, 397-413. 
69. Montesinos, D.; De Luis, M.; Verdú, M.; Raventos, J.; García-Fayos, P. When, how and how much: Gender-specific resource-use strategies in the dioecious tree Juniperus thurifera. Ann. Bot. 2006, 98, 885-889. [CrossRef]

70. Iszkulo, G.; Boratynski, A. Initial period of sexual maturity determines the greater growth rate of male over female in the dioecious tree Juniperus communis subsp. communis. Acta Oecol. 2011, 37, 99-102. [CrossRef]

71. Hofstetter, R.W.; Gaylord, M.L.; Martinson, S.; Wagner, M.R. Attraction to monoterpenes and beetle-produced compounds by syntopic Ips and Dendroctonus bark beetles and their predators. Agric. For. Entomol. 2012, 14, 207-215. [CrossRef]

72. McDowell, N.; Pockman, W.; Allen, C.; Breshears, D.; Cobb, N.; Kolb, T.; Plaut, J.; Sperry, J.; West, A.; Williams, D.; et al. Mechanisms of plant survival and mortality during drought: Why do some plants survive while others succumb to drought? New Phytol. 2012, 178, 719-739. [CrossRef] [PubMed]

73. Mass, M.; Burgos, A. Water Dynamics at the Ecosystem Level in Seasonally Dry Tropical Forests. In Seasonally Dry Tropical Forests. Ecology and Conservation, 1st ed.; Dirzo, R., Young, H., Mooney, H., Ceballos, G., Eds.; Island Press: Washington, DC, USA, 2011; Chapter 9, pp. 141-156. [CrossRef]

74. Poorter, L.; McNeil, A.; Hurtado, V.; Prins, H.; Putz, F. Bark traits and life-history strategies of tropical dry- and moist forest trees. Funct. Ecol. 2014, 28, 232-242. [CrossRef]

75. Devereux, S.; Sabates-Wheeler, R.; Longhurst, R. Seasonality, Rural Livelihoods and Development, 1st ed.; Routledge: London, UK, 2014.

76. Hersch-Martínez, P.; González-Chévez, L.; Alvarez, A. Endogenous knowledge and practice regarding the environment in a Nahua community in Mexico. Agr. Hum. Val. 2004, 21, 127-137. [CrossRef]

77. NOM-005-RECNAT. NORMA Oficial Mexicana NOM-005-RECNAT-1997, Que Establece los Procedimientos, Criterios y Especificaciones para Realizar el Aprovechamiento, Transporte y Almacenamiento de Corteza, Tallos y Plantas Completas de Vegetación Forestal; Secretaria de Medio Ambiente y Recursos Naturales (SEMARNAT): Mexico City, Mexico, 1997.

78. De La O-Toris, J.; Maldonado-Almanza, B.; Martínez-Garza, C. Efecto de la perturbación en la comunidad de herbáceas nativas y ruderales de una elva estacional mexicana. Bot. Sci. 2012, 90, 469-480. [CrossRef]

79. Martínez-Garza, C.; Osorio-Beristain, M.; Valenzuela-Galván, D.; Nicolás-Medina, A. Intra and inter-annual variation in seed rain in a secondary dry tropical forest excluded from chronic disturbance. For. Ecol. Manag. 2011, 262, 2207-2218. [CrossRef]

80. Stockdale, M.; López-Binnqüist, C. Manejo Comunitario Sustentable de Productos Forestales No Maderables. Un Manual para América Latina, 1st ed.; NTFP-EP: Maynila, Philippines; Centro de Investigaciones Tropicales de la Universidad Veracruzana (CITRO-UV): Xalapa, Mexico; Red-PFNM: Mexico City, Mexico; People and Plants International: Bristol, TN, USA, 2019.

81. Hersch-Martínez, P. Commercialization of wild medicinal plants from southwest Puebla, Mexico. Econ. Bot. 1995, 49, 197-206. [CrossRef]

82. Hersch-Martínez, P. Medicinal plants and regional traders in Mexico: Physiographic differences and conservational challenge. Econ. Bot. 1997, 51, 107-120. [CrossRef] 